\title{
INTENSIVE ENGLISH INSTRUCTION IN PESANTREN (STUDY ON PONDOK PESANTREN PUNCAK DARUS SALAM, POTOAN DAJA PALENGAAN PAMEKASAN)
}

\author{
Mohammad Muchlis Solichin \\ (IAIN Madura/muchlisfiqhan@gmail.com)
}

\begin{abstract}
Various pesantren response to the challenge of moderation. One of which is Puncak Darus Salam Pesantren that implement and perform formal education coupled with the establishment of English learning. This paper aims to find 1) the reason of the leader of Pesantren Puncak Darus Salam in organizing the English teaching-learning, and 2) English teaching-learning process in Pondok Pesantren Puncak Darus Salam, Potoan Daja, Palengaan, Pamekasan. This study is qualitative and descriptive. In collecting data, the researcher use observation with non-participant, data were also collected through in-depth interviews and the documentation. Data analysis was used involves 1) data reduction, 2) data display, and 3) conclusions and verification. The research results are 1) The rational reason for the development of learning English is religious reason, that English is seen as a language that can be used for propaganda/ Da'wah of Islam, because of its position as an international language. 2) Development of English learning organized by a specialized organization namely Darwis to use traditional and student-centered learning approach, active learning methods in a regular time each day. 3) Learning English emphasizes the mastery of writing and speaking competence.
\end{abstract}

Keywords:

English, Teaching, Learning, Pesantren Education

DOI: 10.19105/ojbs.v12i12.1991

\section{A. Introduction}

Pesantren is the oldest Islamic institution, whose birth along with the entry of Islam into the archipelago. The propagator of Islam makes pesantren as the media in spreading Islam through education. ${ }^{1}$ However, pesantren face many challenges as a result of social

${ }^{1}$ Manfred Ziemik, Pesantren Dalam Perubahan Sosial transl. Butche B Soendjoyo (Jakarta: P3M Cet. I. 1986, 100. and Kuntowijoyo, Paradigma Islam Interpretasi Untuk Aksi, (Bandung: Mizan, 1990), 57. changes in Indonesian society. Various challenges started from the Dutch government, which initiated the school education system, with the convening of the People's School with the 3-year study period.

The next challenge is originated from Muslim reformers who initiated the changes in the model of Islamic education that is; 1) Inserting sciences of Islam all the public schools, and 2) Establishing a modern madrasa that 
combines general/ non-Islamic sciences, such as English, mathematics, into the curriculum of madrasah.

Various Islamic boarding schools (pesantren) respond to modernize the education system, by entering the general/ non-Islamic sciences into their educational curriculum. In this case, there are some pesantren that maintaining its traditional education and also established formal madrasa under the support of the Ministry of Religious Affairs. When pesantren opened formal madrasa, inevitably learning in the madrasa curriculum should be used in accordance with the Government curriculum.

The above phenomenon is experienced by Pesantren Tebu Ireng Jombang that had been entering profane sciences into the convening of madrasa education. $^{2}$ In 1935 Pesantren Tebuireng organized started madrasa education system, with the name of Nidzâmiyah Madrasah, which is the work of Kiai Wahid Hasyim. This madrasa teaches general knowledge, Dutch and English. The lessons are considered illegitimate in the pesantren at the time. ${ }^{3}$

The entrance of general subjects to the madrasa in Pesantren Tebu Ireng, as leading pesantren in Java and Madura are followed by several pesantren to do the same. From this time, there are many pesantren that

\footnotetext{
${ }^{2}$ Djumhur I and Danasaputra, Sejarah Pendidikan (Bandung: C.V. IImu 1979),159.

${ }^{3}$ Abu Bakar Aceh, Sejarah Hidup K.H. A Wahid Hasyim dan Karangan Tersiar, Jakarta Dharma Bhakti, 1982. 153.
}

implement a traditional education with yellow book teaching-learning, also founded the madrasa and schools education system that follow the government curriculum. ${ }^{4}$

Many Pesantren response to the challenges of modernization, monumentally visible on the establishment of the Pondok Pesantren Modern Gontor in 1926 by three brothers Kiai Ahmad Sahal, Kiai Zainuddin Fanani and Kiai Zarkasyi. Pesantren offers a modern educational system, which was originally only primary education or Ibtidaiyah. Then in 1936, the Pesantren set up junior high schools. Both of these schools are then joined together and named Kulliyatul Muallimin al Islamiyah (KMI). The KMI curriculum consists of subjects of Islamic religious sciences, general studies, and foreign language (Arabic and English).

The study of educational modernization in pesantren carried out by some experts. Zamakhsyari Dohfier examines pesantren (it general characteristics, elements of a pesantren, intellectual and kinship relations among kiai, the notion of Ahlus Sunnah walJama'ah). In connection with the educational reform of pesantren, historically and sociologically, Dhofier discusses educational reform of pesantren education that occurs at Pesantren Tebuireng Jombang, with the

\footnotetext{
${ }^{4}$ Karel A Steenbrink, Pesantren, Madrasah dan Sekolah: Pendidikan Islam dalam Kurun Modern, Jakarta LP3ES, 1994. 120.
} 
implementation of madrasah education and public schools. ${ }^{5}$

In line with Dhofier, Karel A Steenbrink examines Islamic educational reforms dealing with secular education. ${ }^{6}$ The same study was done by Sukamto who examined the pesantren education system when the implementation of the madrasa education and school/college by taking the case in Pondok Pesantren Darul Ulum Jombang. ${ }^{7}$ Furthermore, Imron Arifin discusses the changes in the educational system in Pesantren Tebuireng. ${ }^{8}$

A patterned philosophical study conducted by Yasmadi. His study examines the objective condition of Pesantren, formulating objectives of pesantren education, narrowing the curriculum orientation, historical and philosophical foundation of educational reform of pesantren. In addition, he discussed the renewal of Islamic education in view Nurcholish Madjid as an integration between Islamic perspective and Indonesian tradition. ${ }^{9}$

Meanwhile, Ronald Alan Lukens examines the history and characteristics

\footnotetext{
${ }^{5}$ Zamakhsyari Dhofier, Tradisi Pesantren: Studi tentang Pandangan Hidup Kyai (Jakarta: LP3ES, 1987).

6 Steenbrink, Pesantren, Madrasah, Sekolah: Pendidikan Islam dalam Kurun Waktu Modern (Jakarta: LP3ES, Cet. II) 1994.

7 Sukamto, Kepemimpinan Kiai dalam Pesantren( Jakarta: LP3ES, 1999)

${ }^{8}$ Imron Arifin, Kepemimpinan Kiai, Kasus Pondok Pesantren Tebuireng (Malang: Kalimashada Press, 1993).

9 Yasmadi, Modernisasi Pesantren: Kritikaan Nurcholish Madjid Terhadap Pendidikan Islam Tradisonal (Jakarta: Ciputat Press, 2002)
}

of pesantren, educational reform of the pesantren in the context of developmental curriculum to be implemented in madrasa, public schools, colleges of Pondok Pesantren Tebuireng in Jombang (he meant by secular education along with religious education). His study also held in Pondok Pesantren al-Nur in Malang. Lukens call with the pesantren that combine religious education with secular education. $^{10}$

The philosophical study also conducted by Nurcholish Madjid, which examines pesantren in ideal conditions with a formulation of the purpose of pesantren education. ${ }^{11}$ Dian Nafi M. et al. examines the purpose and methods of pesantren education and praxis of effective pesantren education. ${ }^{12}$

Historically studies conducted by M. Habib Chirzin which addresses the educational system and curricula (subject matter) at the pesantren before it's modernization, the changes in pesantren, particularly in relation to the educational system. These resulted in the changes in curriculum and methods teaching in Pesantren Tebuireng and Pesantren Modern Gontor. ${ }^{13}$

10 Ronald Alan Lukens, Jihad ala Pesantren Di Mata Antropolog Amerika, terj. Abdrurrahman Mas'ud( Yogyakarta: Gema Media, 2004)

11 Nurcholish, Madjid, Bilik-Bilik Pesantren: Sebuah Potret Perjalanan (Jakarta: Paramadina, 1997)

12 M. Dian Nafi et. al, Praksis Pembelajaran Pesantren (Yogyakarta: LKiS Pelangi Aksara, 2007).

${ }^{13}$ Chirzin, M. Habib, "Ilmu dan Agama dalam Pesantren" dalam Pesantren dan Pembaharuan, ed. M. Dawam Rahardjo (Jakarta: LP3ES, 1995. 
Pondok Pesantren Puncak Darus Salam Potoan Daja, Palengaan, Pamekasan is a pesantren that implements the traditional pesantren and performs formal education institutions of secondary school and high school, coupled with the establishment the English Course, were the effort in equipping knowledge and skills that are needed in this period.

This paper aims to find 1) the rationale thought the leader of Pesantren Puncak Darus Salam organizes the English teaching-learning, 2). English teaching-learning process in Pondok Pesantren Puncak Darus Salam, Potoan Daja, Palengaan, Pamekasan.

\section{B. Method}

This study is qualitative and descriptive. This type of research is more emphasizes on the process than the results, the analysis of the data used is inductive. The researcher is intended to understand the phenomenon being studied. ${ }^{14}$

In gathering the data, the researcher used direct and nonparticipant observation, the researcher collect the data in this study using: 1) direct observation and non-participant; namely researcher directly observes and engages in activities the object to determine the phenomena relevant to the issues and objectives of the

14 Robert C. Bogdan dan S. Knoop Biklen, Qualitative Research for Education: An Introduction to Theory and Method. (Boston: Allyn and Bacon, n.d.), 2 research, the systematic disclosure to test the hypothesis.

Data were also collected through in-depth interviews. By using this type of interview, the researcher conducted a research that is naturally growing in the research area. While, the types of interviews used open-ended interviews, which is a type of interview provides an opportunity for the researcher to be able to ask respondents their views on the facts and/or data into the research findings.

Researcher determines key informants, the respondent gave a lot of information for the researcher. The key informant was very helpful to get the particulars to the researcher, and can also provide information on sources of other information.

While the documentation used to add to the evidence and research resources, which can serve to verify the names and titles acquired in the interview, adding specific details to support information and other resources as well as making the inference of these documents.

Data analysis in qualitative research is characterized by a process carried out in three stages, ${ }^{15}$ namely: (a) data reduction, (b) display the data, and (c) conclusions and verification.

\footnotetext{
${ }^{15}$ Lexy J. Moleong, Metodologi Penelitian Kualitatif, (Bandung: Remaja Rosdakarya, 1998), 103.
} 


\section{Results}

Pondok Pesantren Puncak Darussalam is an institution in Potoan Daya village, Palengaan, Pamekasan. The Institution established a formal and informal education institutions fully integrated into a full-time teaching in the form of Islamic Boarding School.

The brief background of Puncak Darussalam Institution was started in 2005, coming from the trust of the people around who sent their sons to study about Islamic religion after every sunset prayer, or more specifically, they studied the yellow book as the development of religious understanding. Then in 2007, this institution began to gain the trust of the public who entrusts his sons to study or reside in the boarding school. Nevertheless, students who wish to formal schooling, they must attend to Banyuanyar to walk about $2 \mathrm{~km}$ or $4 \mathrm{~km}$ round trip. Therefore, to meet the needs of students to formal education, then in 2008, they officially opened the formal education of Banyuanyar that continue to the present.

Based on the above background, the Pondok Pesantren Darussalam wishes to set up a future generation which have multiple competencies, which is a generation who are competent in the field of religion and qualified in the field of science and technology, and is always oriented to compliance with the Islamic Shari'a and have contributed in building religious life, nation and the state, as well as actively participate in managing the world's civilization. Besides, it is driven by the number of shoots with huge potential to grow into a future generation of high quality if guidance were really focused and intensive.

Thus, the Pondok Pesantren Puncak Darussalam establish formal school consisting of Islamic high school with a curriculum specially packaged integrally, directed, and have a clear orientation, which is a curriculum that is projecting learners to be able to understand the Al-Quran through the deepening of interpretation, as well as the procurement of Science, Technology and English. It is an attempt to reflect the increasingly urgent needs of the times that will be the presence of an education system that harmonizes traditional and modern education system, textually and contextually, intellectual, emotional and spiritual.

Based on the above requirements as well as the social conditions that increasingly plunged into multidimension crisis like the crisis of faith, moral decadence and the advancement of science and technology is so fast in the reality of modern life. Pondok Pesantren Darussalam is wanted to contribute in preparing next generations who have multi-skills and high morale to participate in developing the order of a harmonious, balanced and religious world, in the form of formal education. The Pesantren fully integrated with the strength of the two pillars of ulul albab generations, the spiritual and intellectual question. 
The education system of Pondok Pesantren Puncak Darussalam is using the system for guidance, so that all students' development can be controlled over time, both in terms of scientific developments, crafts, and in worship, because the results of the students reported on a regular basis every month to caretakers as a form of responsibility of the board in carrying out its duties, This system still needed an improvement of various aspects as concrete steps in order to seek educational improvement

Pondok Pesantren Darussalam implemented a curriculum that integrated with the Ministry of Education curriculum so that they have a target of achieving an integrated and competency standards at every level. In the junior level is targeted to achieve mastery learning and undergoing various tests like memorizing 3 Juz of Al-Quran from behind, and capable of interpreting Ayatul Aahkam with Arabic/ English corresponding curriculum.

\section{The Reasons for English Language Learning Development in Pondok Pesantren Darus Salam}

Development of English Learning in Pondok Pesantren Puncak Darus Salam Establish English learning organization that is specially called "DARWIS", it is a special organization established under controlled by Pondok Pesantren Puncak Darus Salam. This intensive English learning organization is assumed can be an important facility for students who want to learn English. The development of English program in this pesantren is started in 2009 based on the initiative K.H. Abd. Hannan Tibyan, the leader of Pondok Pesantren Darussalam. He thinks that it is important to master the English language.

In addition to transferring the message of Islam on people in all parts of the world, English can be a bridge for the students to be sensitive to the development of knowledge throughout the world. In addition, the development of learning English based on his idea that it is the duty of all Muslims to spread and convey Islam to all of mankind, wherever they are. While it was not all the people of the world understand the messages conveyed propaganda in Arabic, especially those who do not use Arabic in life. That requires a medium to deliver / propagation of Islam that can be understood by the majority of mankind.

English as a language is believed to be a dominant language in the world, considering English is as an international language and is used by most of the nations. To be able to master in English and can communicate by using English. It is considered important to develop learning English by which the students can convey messages to the entire Islamic world Society. 
The above explanation, also corroborated by the explanation by Hariyadi, the leader of DARWIS, he states that the purpose of this organization is as a bridge for Pupils to learn English as an international language, especially related to Islamic studies. So, this organization is not only focused on understanding the language or culture of the west but also facilitate students to deepen their understanding of Islam.

This organization has a large number of reasons why integrating English with Islamic studies to be important today. Muslims must recognize the importance of the English because they must follow the development of civilization and culture in order to update and grew into a modern person. So, what should be done today does not abstain but welcoming and controlling. More than that, how to become a public speaker (Preacher) is also one of great competence to be considered and developed so that they have the ability to speak English, in addition to good personal principle, as the basis to invite others to Islam.

\section{Development Process of English Learning in Pondok Pesantren Darus Salam.}

English Learning Development begins with the establishment of the organization namely "DARWIS". After that DARWIS started to develop and success in attracting the students' attention. They are really aware of the importance of English. It took one year that the organization leader struggled to motivate its members and guide them with various kinds of programs such as small group discussions, presentations, grammar, listening to understanding studies. Some programs are still running to this day even though there are still some things that need to be improved. This institution has a large number of excellent programs and integrated with various other facilities that sustain the comfort of members in the learning process.

While the mission of developing English teaching-learning is as follows: 1) Broadening the students' understanding of Islam by discussions and presentation using English, 2) Creating the students which expert in Islam and English, 3) Producing professional graduations that can utilize their knowledge to advance religion, education, and race.

While the basic purpose of this institution is by development of English learning, the students are expected to understand the English correctly both oral and written form. They are also expected to present the basic values of Islamic culture. We hope they can become leaders who have great ability to bring Islam to the glory.

To achieve the learning objectives above, it is necessary to 
make teachers to use learning approaches below, namely: 1) Asking the member to look for as much information about the material to learn, 2) Using a variety of learning approaches, media, and learning resources, 3) Maximizing the interaction between members and teacher, and 4) Stimulating members to be active in each learning activity.

In this approach, teacher is expected to: 1) allows the students to read and write with the various tasks assigned, 2) leads them through discussions, study groups, and others to inspire (bring) a new concept, 3) gives them a chance to think, analyze, problem solving, and dare to act, 4) directing them to compete fairly to improve and develop the learning achievement. 5) Providing a point value in each task assigned either individually or in groups.

In this approach, teacher 1) provides a good appreciation of the achievements of the participants, 2) provides an open opportunity for participants to confirm the test results and asked them to consider previous learning experiences, 3) can answer all the questions from the participants related to the subjects that they do not understand yet, 4) helps participants to solve problems. 5) Providing related references so that they can check the results of their English learning. 6) Provide motivation to those who are in the weak spirit.
Establishment and development of educational organization like DARWIS is an effort to create conditioning in learning. The conditioning is in accordance with the theory of classical conditioning by Ivan Pavlov, ${ }^{16}$ Application of the theory of Classical Conditioning in learning, conditioning is a form of learning that allows the organism to respond to a stimulus that previously did not generate the response, or a process to introduce a variety of reflexes into a behavior. So, classical conditioning is used as a shaper of behavior through the required (conditioning process). Pavlov assumed that the behavior of an organism can be established through regulation and manipulation of the environment. This theory is often referred to as contemporary Behaviorists or also called StimulusRespond. The Psychologist who found that human behavior is controlled by rewards or reinforcement of the environment. In other words, habituation will occur if the exercise is done repeatedly. ${ }^{17}$

\footnotetext{
16 Suyono, Belajar dan Pembelajaran (Bandung, PT. Remaja Roskadarya, 2014), 60. B. Uno, Orientasi Baru dalam Psikolgi Pembelajaran (Jakarta: PT Bumi Aksara, 2012), 19. Nana Syaodih Hamzah Sukmadinata, Landasan Psikologi Proses Pendidikan (Bandung: PT Rosda Karya, 2011), 168. Sardiman A.M, Interaksi dan Motivasi Belajar Mengajar (Jakarta: PT Raja Grafindo Persada, 2010), 29.

17 Dale H. Schunk, Teori-Teori Pembelajaran: Perspektif Pendidikan, terj. Eva Hamdiah dan Rahmat Fajar (Yogyakarta: Pustaka Pelajar, 2012), 109. G.A. Kimble, N. Garmezy \& E. Zigler,
} 
The purpose of learning English in the pesantren is to make the students can communicate using English as the language of instruction. Operationally, learning programs emphasized the ability to write and submit papers in the form of lectures. In the early stages, students are guided to be able to write a simple sentence that tells the day-to-day activities. The next step is to assemble into a single sentence paragraph. Furthermore, students are guided to be able to make essay in a simple form. In the final stage, teachers guide students in the development of a more complex essay.

Learning English emphasizes on the mastery of writing and speaking competence of students. Meanwhile, the competence of reading, listening (listening) is an additional competency as development.

At the beginner level (elementary) of the writing materials, teachers explain the words in English and meaning in Indonesian. It starts from the noun, pronoun, adjective, verb preposition, conjunctions, and interjections. Every part of the words above is written in some sentences related to everyday activities, like I wrote a letter, I go to school every day, my friend helped me to complete the task, the teacher teaching the class, and others. While the competence of speech begins with

Principles of General Psychology (New York: John Wiley \& Sons, Inc, 1974), 208. Muhibbin Syah, Psikologi Belajar, $5^{\text {th }}$ Edition. (Jakarta: PT Raja Grafindo Persada, 2006), 30-33. saying thank and apologizing, getting and farewell, command, request, prohibiting, invitation, advice, suggestion, introduction, days and month, how to say numbers in English, the numbers in Islam, time in English, and the months in Islam.

At the stage, the student can draw a conclusion from something in real situations or by using concrete objects because at this time they have sufficient logical thought. It is important during the sorting process is to sort objects based form or size, or other characteristics.

At the intermediate level, the teacher explains the kinds of sentences, involve: a declarative sentence, interrogative sentence, imperative sentence, exclamatory sentence, and tenses in English. Also, include getting to know a paragraph, topic sentence, the body of the paragraph, the paragraph structure, and a conclusion of a paragraph. Meanwhile, the competence of speaking is talking about past experience, describing pictures, telling about a picture (camping in the forest), telling about future plans, telling action in order, giving a direction, speak with courtesy in telephone.

At the advanced level, the teacher explains the type of text in English: explanation, narrative, discussion, argumentative, reports, procedures, recount, descriptive, and writing an essay. Furthermore, in speaking competence, the teacher explains the public speaking, the text of the Master of Ceremony, English speech, text of news 
reading, the text of the story telling, the text of English poem, and song lyrics.

Formal operational stage occurred in children aged 11 years and over, the person's cognitive activity is not necessarily using real objects. At this stage, the ability to reason abstractly increased so that one is able to think deductively. At this stage also, one is able to consider several aspects of the situation together. ${ }^{18}$

There are intensive classes because ability students are not the same, then to provide a common understanding of English. An intensive class was held for those who have low ability. There is an English language development program within the competence of writing and speaking/speech (speech). This program is held two weeks. The program is a reinforcement program for the students to have the ability both in speech and writing.

\section{Conclusion}

1. The reason for the development of learning English is religious reason. English is seen as a language that can be used for Islamic Da'wah, because English is used as an international language.

18 Robert E. Slavin, Educational Psychology : Theory and Practice, Terj. Marianto Samosir Edisi Kedelapan (Jakarta: PT Indeks, 2008). 43; Anita Woolfolk, Educational Psychology Active Learning Edition, Terj. Helly Prajitno Soetjipto dan Sri Mulyani Soetjipto Edisi Kesepuluh (Yogyakarta: Pustaka Pelajar, 2009), 45.
2. Development of English learning organized by a special organization namely DARWIS. They use traditional approach that is student-centered learning in English teaching-learning. They also implement active learning methods in a regular time each day. While the purpose of the development of English institutions is to produce graduations who have the ability to have good public speaking, and to use that ability as a vehicle of Da'wah to the throughout the world.

3. Learning English emphasis on the mastery of writing and speaking competence of students. Meanwhile, the competence of reading (reading), listening (listening) is additional competency as development. At the beginner level (elementary) writing materials, teachers explain the words in English language and meaning in Indonesian. At the intermediate level, the teacher explains the kinds of sentences. At the advanced level, the teachers explain the type of text in English, and public speaking.

\section{References}

Aceh, Abu Bakar, Sejarah Hidup K.H. A Wahid Hasyim dan Karangan Tersiar, Jakarta Dharma Bhakti, 1982.

Arifin, Imron, Kepemimpinan Kiai, Kasus Pondok Pesantren Tebuireng, Malang: Kalimashada Press, 1993. 
Bogdan, Robert C.and S. Knoop Biklen, Qualitative Research for Education: An Introduction to Theory and Method. Boston: Allyn and Bacon, n.d.

Chirzin, M. Habib, "Ilmu dan Agama dalam Pesantren" dalam Pesantren dan Pembaharuan, ed. M. Rahardjo, Dawam Jakarta: LP3ES, Cet. V, 1995.

Dhofier, Zamakhsyari Tradisi Pesantren: Studi tentang Pandangan Hidup Kyai .Jakarta: LP3ES, 1987.

I, Djumhur dan Danasaputra, Sejarah Pendidikan, Bandung: C.V. IImu 1979.

Kimble, G. A. N. Garmezy \& E. Zigler, Principles of General Psychology New York: John Wiley \& Sons, Inc, 1974.

Kuntowijoyo, Paradigma Islam Interpretasi Untuk Aksi, Bandung: Mizan, 1990.

Lukens, Ronald Alan. Jihad ala Pesantren d Mata Antropolog Amerika, terj. Abdrurrahman Mas'ud. Yogyakarta: Gema Media, 2004.

Madjid, Nurcholish, Bilik-Bilik Pesantren: Sebuah Potret Perjalanan , Jakarta: Paramadina, 1997.

Moleong, Lexy J. Metodologi Penelitian Kualitatif, (Bandung: Remaja Rosdakarya, 1998.

Nafi, M. Dian et. al., Praksis Pembelajaran Pesantren, Yogyakarta: LKiS Pelangi Aksara, 2007.
Sardiman, A. M. Interaksi dan Motivasi Belajar Mengajar. Jakarta: PT Raja Grafindo Persada, 2010.

Schunk, Dale H. Teori-Teori Pembelajaran: Perspektif Pendidikan, terj. Eva Hamdiah dan Rahmat Fajar, Yogyakarta: Pustaka Pelajar, 2012.

Slavin, Robert E. Educational Psychology: Theory and Practice, Terj. Marianto Samosir Edisi Kedelapan. Jakarta: PT Indeks, 2008.

Steenbrink, Karel A Pesantren, Madrasah dan Sekolah: Pendidikan Islam dalam Kurun Modern. Jakarta: LP3ES, 1994.

Sukamto, Kepemimpinan Kiai dalam Pesantren. Jakarta: LP3ES, 1999.

Sukmadinata, Nana Syaodih Hamzah, Landasan Psikologi Proses Pendidikan. Bandung: PT Rosda Karya, 2011.

Suyono, Belajar dan Pembelajaran. Bandung: PT. Remaja Roskadarya, 2014.

Syah, Muhibbin. Psikologi Belajar, $5^{\text {th }}$ edition, Jakarta: PT Raja Grafindo Persada, 2006.

Uno, Hamzah. Orientasi Baru dalam Psikolgi Pembelajaran. Jakarta: PT Bumi Aksara, 2012.

Woolfolk, Anita. Educational Psychologi Active Learning Edition, Terj. Helly Prajitno Soetjipto and Sri Mulyani Soetjipto. Yogyakarta: Pustaka Pelajar, 2009. 
Yasmadi. Modernisasi Pesantren:

Kritikaan Nurcholish Madjid

Terhadap Pendidikan Islam

Tradisonal. Jakarta: Ciputat

Press, 2002.

Ziemik, Manfred. Pesantren dalam

Perubahan Sosial ter. Butche B

Soendjoyo. Jakarta: P3M, Cet.

I. 1986. 